\title{
Targeting Complement C3a Receptor to Improve Outcome After Ischemic Brain Injury
}

\author{
Marcela Pekna ${ }^{1}$ D $\cdot$ Anna Stokowska ${ }^{1} \cdot$ Milos Pekny $^{2}$ D
}

Received: 30 June 2021 / Revised: 30 June 2021 / Accepted: 19 July 2021 / Published online: 11 August 2021

(c) The Author(s) 2021

\begin{abstract}
Ischemic stroke is a major cause of disability. No efficient therapy is currently available, except for the removal of the occluding blood clot during the first hours after symptom onset. Loss of function after stroke is due to cell death in the infarcted tissue, cell dysfunction in the peri-infarct region, as well as dysfunction and neurodegeneration in remote brain areas. Plasticity responses in spared brain regions are a major contributor to functional recovery, while secondary neurodegeneration in remote regions is associated with depression and impedes the long-term outcome after stroke. Hypoxic-ischemic encephalopathy due to birth asphyxia is the leading cause of neurological disability resulting from birth complications. Despite major progress in neonatal care, approximately $50 \%$ of survivors develop complications such as mental retardation, cerebral palsy or epilepsy. The $\mathrm{C} 3 \mathrm{a}$ receptor $(\mathrm{C} 3 \mathrm{aR})$ is expressed by many cell types including neurons and glia. While there is a body of evidence for its deleterious effects in the acute phase after ischemic injury to the adult brain, C3aR signaling contributes to better outcome in the post-acute and chronic phase after ischemic stroke in adults and in the ischemic immature brain. Here we discuss recent insights into the novel roles of $\mathrm{C} 3 \mathrm{aR}$ signaling in the ischemic brain with focus on the therapeutic opportunities of modulating C3aR activity to improve the outcome after ischemic stroke and birth asphyxia.
\end{abstract}

Keywords C3a $\cdot \mathrm{C} 3 \mathrm{a}$ receptor $\cdot$ The complement system $\cdot$ Brain ischemia $\cdot$ Ischemic stroke $\cdot$ Hypoxic-ischemic encephalopathy $\cdot$ Birth asphyxia $\cdot$ Neural plasticity $\cdot$ Neuroprotection $\cdot$ Recovery

\section{Introduction}

Each year, stroke affects about 15 million people worldwide. $50 \%$ of the approximately 10 million stroke survivors suffer from long-lasting or permanent functional impairment, which makes stroke the primary cause of disability in adults. Stroke most commonly results from the occlusion of a major

Special issue: In Honor of Vladimir Parpura.

Marcela Pekna

Marcela.Pekna@neuro.gu.se

1 Laboratory of Regenerative Neuroimmunology, Center for Brain Repair, Department of Clinical Neuroscience, Institute of Neuroscience and Physiology, Sahlgrenska Academy, University of Gothenburg, Box 440, 40530 Gothenburg, Sweden

2 Laboratory of Astrocyte Biology and CNS Regeneration, Center for Brain Repair, Department of Clinical Neuroscience, Institute of Neuroscience and Physiology, Sahlgrenska Academy, University of Gothenburg, Gothenburg, Sweden vessel in the brain. If the occlusion is not rapidly reversed, an infarct develops due to the death of all cells in the affected tissue. Only a small fraction of patients arrive at the hospital in time to be eligible for blood clot removing procedures. Rehabilitation - that only rarely leads to full recovery - remains as the only option for the majority of stroke survivors. Therefore, improving recovery of function by effective neuroprotection, and plasticity- and regeneration-promoting strategies has become a major research focus.

Loss of function after stroke is due to cell death in the infarcted tissue and cell dysfunction in the surrounding as well as remote brain regions that are connected to the damaged area. Recovery of function involves reversal of dysfunction, activation of cell repair (cell genesis, axonal regeneration), functional reorganization within existing networks (changing the properties of existing neural pathways) and neuroanatomical plasticity leading to the formation of new connections (axonal sprouting, synaptogenesis). Some of these mechanisms, jointly called neural plasticity, are involved in normal learning, are enhanced by the milieu 
created following the injury, and contribute to recovery of function after stroke and other CNS injuries [1].

Hypoxic-ischemic encephalopathy is one of the most critical pathologic conditions in neonatal medicine. Neonatal hypoxic-ischemic encephalopathy due to perinatal asphyxia is the leading cause of neurological disability resulting from birth complications. It is caused by the disruption of blood flow and oxygen supply to the brain prior to or during delivery and occurs in 1-2 of 1000 live term births. Recent advances in critical care have improved the survival of infants suffering from hypoxic-ischemic encephalopathy, but approximately $50 \%$ of survivors will develop complications such as mental retardation and cerebral palsy. Long-term neurological impairment after neonatal hypoxiaischemia correlates with the extent of brain damage [2]. Perinatal asphyxia and other perinatal brain insults lead to neuronal cell death in the acute and secondary phases, which last for hours to days; delayed neuronal cell death in the so-called tertiary brain damage phase, which can persist for weeks to years, prevents repair and regeneration, disturbs the development and function of affected brain networks, or sensitizes them to dysfunction and cell death due to a subsequent inflammatory challenge [3]. Even a mild-tomoderate ischemic insult can result in progressive cerebral atrophy, delayed infarction, and long-term cognitive impairment in rodent hypoxic-ischemic encephalopathy models [2, 4-8]. However, the underlying mechanisms are not fully understood. Therapeutic hypothermia is a clinically accepted therapy for hypoxic-ischemic encephalopathy, however, treatment of eight children is required for one child to be saved from the development of severe disability. Therapies to further improve outcomes of infants suffering from acute encephalopathy are therefore urgently needed [9].

The complement system is an important constituent of the humoral innate immune response best known for its role in the elimination of pathogenic bacteria and initiation of inflammation. The complement system consists of more than 50 soluble proteins, cell receptors and control proteins found in the blood and tissues. Their specific roles in innate immunity include the opsonization and lysis of pathogens, elimination of soluble antigen-antibody complexes, removal of dead cells and tissue debris, stimulation of leukocyte chemotaxis, and initiation of inflammation. Through the regulation of B and T lymphocyte functions, complement affects also adaptive immunity [10]. Hepatocytes are the main source of soluble complement proteins, however many complement factors and receptors are also expressed locally in the brain and spinal cord [10]. The complement system mediates the reciprocal signaling between the cells in the CNS and acts as both the modulator and effector of their functions [11].

$\mathrm{C} 3 \mathrm{a}$ receptor $(\mathrm{C} 3 \mathrm{aR})$ is a $\mathrm{G}$-protein-coupled receptor for a cognate complement-derived peptide $\mathrm{C} 3 \mathrm{a}$ [12]. C3aR is expressed in many tissues including the brain $[13,14]$.
Besides its many functions in the regulation of inflammation [15], C3aR has been shown to play a role in the development and normal function of the CNS, however excessive C3aR signaling has been implicated as a factor in neurodegeneration. In the ischemic brain, signaling through $\mathrm{C} 3 \mathrm{aR}$ can both contribute to tissue damage and stimulate neural plasticity responses involved in functional recovery. $\mathrm{C} 3 \mathrm{aR}$ represents an attractive target for the treatment of ischemic brain injury, however, for the optimal outcome neurodevelopmental stage, the mode of interaction as well as timing of the intervention seem to be of critical importance.

\section{C3aR in CNS Development and Function}

$\mathrm{C} 3 \mathrm{aR}$ is a member of the rhodopsin family of seven transmembrane G-protein-coupled receptors [12]. As the name implies, $\mathrm{C} 3 \mathrm{aR}$ was identified as the receptor for $\mathrm{C} 3 \mathrm{a}$, a $9 \mathrm{kDa}, 77$ amino acid peptide and the smaller of the two activation fragments generated through the proteolytic activation of the third complement component (C3), the central molecule of the complement system [12]. Beside the so called C3-convertases, i.e. enzymatic complexes generated by the complement cascade triggered by e.g. danger associated signals on the surface of pathogenic microorganisms, C-reactive protein and amyloid- $\beta$ [16], C3a can be released through the proteolytic activation of $\mathrm{C} 3$ by a number of other membrane-associated or serine proteases such as mannanbinding lectin-associated serine protease 1 [17], neutrophil elastase, cathepsins [18, 19], granulocyte neutral proteases [20], lysosomal enzymes, kallikrein, as well as coagulation factors XIa, Xa, IXa, thrombin, and plasmin [21, 22]. In addition to $\mathrm{C} 3 \mathrm{a}, \mathrm{C} 3 \mathrm{aR}$ has been shown to bind the neuropeptide TLQP-21 [23], that is derived from the neurotrophininducible protein VGF through proteolytic cleavage by prohormone convertases $1 / 3$ and 2 [24], Fig. 1.

$\mathrm{C} 3 \mathrm{aR}$ is expressed by embryonic stem cells [25], neural progenitor cells [26] and mature neurons [27-30]. In neural progenitor cells, C3a-C3aR signaling activates the extracellular signal-regulated kinase (ERK)1/2 signaling pathway, regulates neuronal differentiation, neuronal maturation and migration [31]. C3a was also shown to accelerate the migration of granule cells of the developing cerebellum [32] and regulate neuronal migration during cortical development [33]. The neurodevelopmental role of C3aR signaling is evidenced by altered brain morphology, cognitive defects and hyperactive behavior observed in adult mice constitutively lacking C $3 \mathrm{aR}[25,34]$. C3aR stimulates neurogenesis in adult naïve mice [26] and normal level of neuronal C3aR signaling is required for synaptic plasticity and maintenance of normal dendritic extensions [35].

Astrocytes express C3aR $[27,28,36]$ and respond to C3a by activation of intracellular signaling [37] and the 
Fig. 1 C3a and TLQP-21 are endogenous ligands of $\mathrm{C} 3 \mathrm{aR}$ in the CNS. C3a can be released through the proteolytic activation of $\mathrm{C} 3$ by $\mathrm{C} 3$-convertases, coagulation factors XIa, Xa, IXa, thrombin, and plasmin, cathepsins and a number of other membrane-associated or serine proteases such as mannan-binding lectin-associated serine protease 1 , neutrophil elastase, granulocyte neutral proteases, lysosomal enzymes, and kallikrein. The neuropeptide TLQP-21 is derived from the neurotrophin-inducible protein VGF through a stepwise proteolytic cleavage by prohormone convertases $1 / 3$ and 2

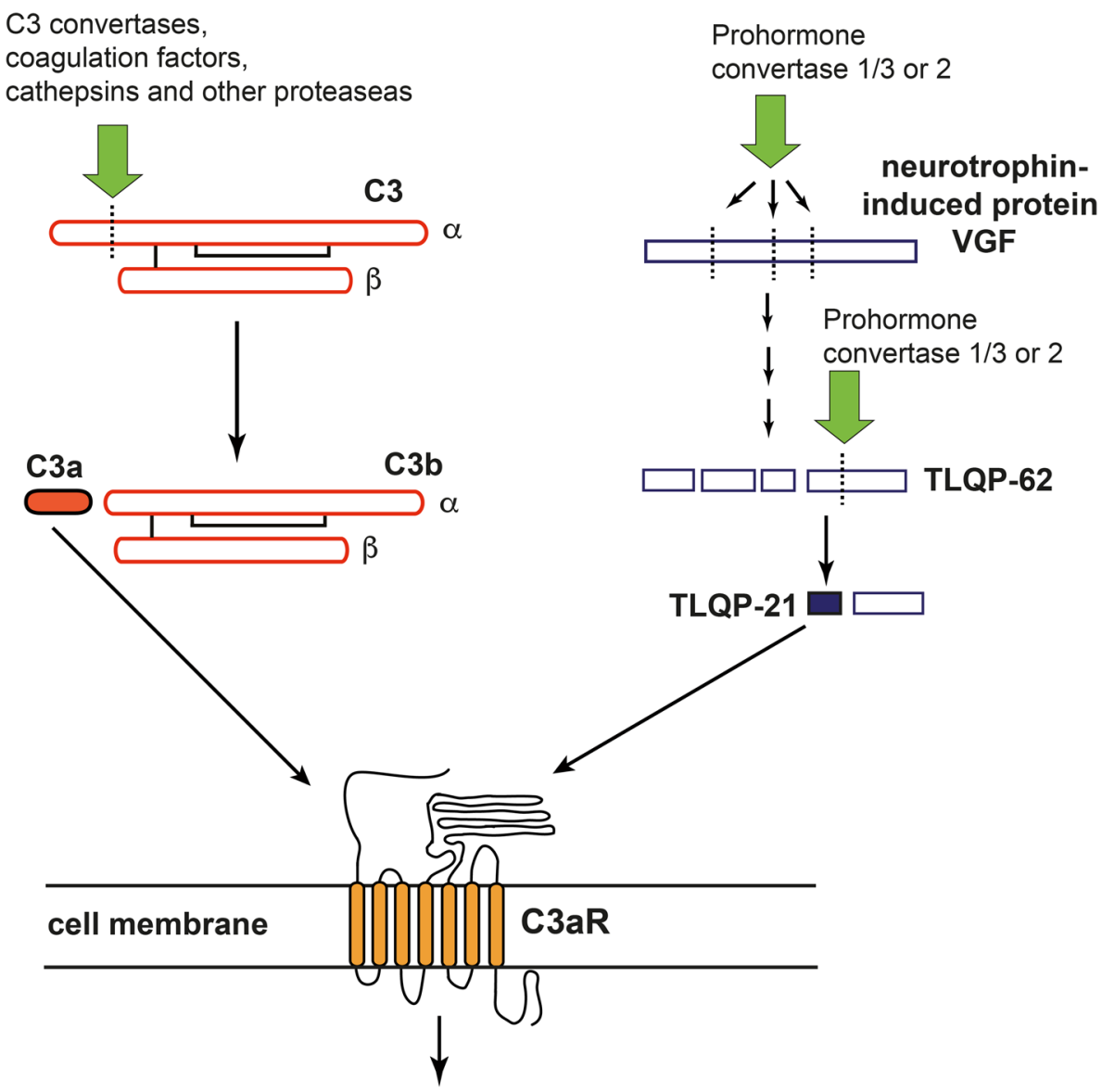

expression of cytokines such as interleukin (IL)-6, IL-8 and nerve growth factor (NGF) [38-40].

Microglia express C3aR and C3a stimulation of microglia triggers an increase in intracellular calcium concentration [41] and upregulation of NGF [42]. C3aR-mediated signaling regulates the phagocytic activity of microglia, short exposure to $\mathrm{C} 3$ a stimulates and chronic $\mathrm{C} 3$ a treatment reduces microglial phagocytosis [43]. Activation of microglial C3aR by TLQP-21 in the dorsal horn of the spinal cord has been implicated in spinal neuroplasticity and neuropathic pain [44], however the functions of TLQP-21 in the brain and its role in the brain responses to ischemia have not been studied.

$\mathrm{C} 3 \mathrm{aR}$ signaling increases vascular permeability, stimulates smooth muscle contraction, and triggers the activation and directed migration of inflammatory cells [13]. $\mathrm{C} 3 \mathrm{aR}$ regulates endothelial cell expression of cytokines and adhesion molecules, which are important for leukocyte recruitment into the brain, and control blood brain barrier permeability [45-47]. Activation of C3aR signaling on epithelial cells of the choroid plexus can lead to the disruption of blood-cerebrospinal fluid barrier [48].
The multiple effects of C3aR signaling on the function of the different cell types in the CNS are summarized in Table 1.

\section{C3aR and Intracellular Signaling}

In various cell types such as microglia, astrocytes and endothelial cells, C3aR activates the phospholipase $\mathrm{C}$ pathway leading to the opening of intracellular calcium channels and increase in the intracellular calcium levels [37, 41, 47]. C3a-C3aR signaling modulates the activity of the ERK1/2 pathway including Ras and c-Raf [31, 37, 49]. At least in astrocytes, stimulation of $\mathrm{C} 3 \mathrm{aR}$ leads to the inhibition of the adenylyl cyclase pathway [37]. In microglia, C3a-C3aR signaling was shown to increase the phosphorylation and activation of STAT3 [50]. C3aR antagonist SB290157 reduced the inhibitory Ser9 phosphorylation of glycogen synthase $3 \beta$ (GSK3 $\beta$ ) in the SH-SY5Y neuroblastoma cells [51], pointing to the role of $\mathrm{C} 3 \mathrm{aR}$ signaling in the regulation of GSK3 $\beta$ activity, Fig. 2. 
Table 1 The effects of C3aR signaling on the cells in the CNS

\begin{tabular}{lll}
\hline Cell type & C3aR functions & References \\
\hline Neural stem / progenitor cells & Neuronal differentiation & {$[31]$} \\
& Migration & {$[31]$} \\
Neurons & Migration & {$[32,33]$} \\
& Neurite outgrowth & {$[31]$} \\
& Modulation of synaptic strength & {$[35]$} \\
& Modulation of dendritic morphology & {$[35]$} \\
Astrocytes & Cytokine expression & {$[38-40]$} \\
& Survival & {$[36]$} \\
Microglia & NGF upregulation & {$[42]$} \\
& Regulation of phagocytosis & {$[43]$} \\
Endothelial cells & Cytokine expression & {$[45]$} \\
& Expression of cell adhesion molecules & {$[46]$} \\
Epithelial cells of the choroid plexus & Disorganization of tight junctions & {$[48]$} \\
\hline
\end{tabular}

Fig. 2 Intracellular signaling pathways regulated by $\mathrm{C} 3 \mathrm{aR}$ in the cells of the CNS.In microglia, astrocytes and endothelial cells, C3aR signaling inhibits the adenylyl cyclase pathway and reduces the inhibitory Ser9 phosphorylation of glycogen synthase $3 \beta$ (GSK3 $\beta)$. C $3 a R$ signaling activates the phospholipase $\mathrm{C}$ pathway, modulates the activity of the extracellular signal regulated kinase $1 / 2$ (ERK1/2) pathway, and activates STAT3

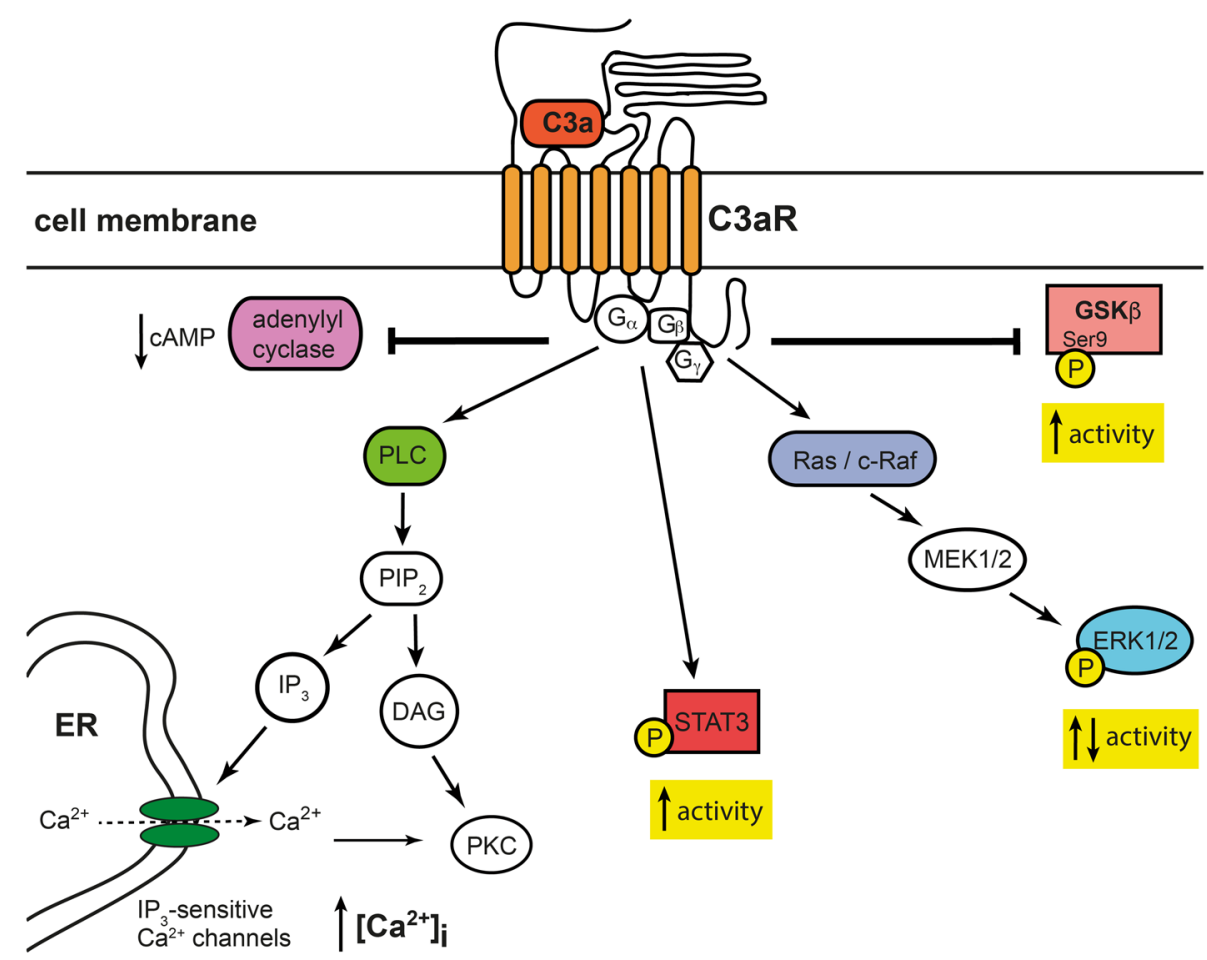

\section{The Roles of C3aR in the Ischemic Brain}

Astrocytes, microglia and neurons are the source of complement proteins in the CNS [52-55]. After brain ischemia, pronounced complement activation was reported both in the systemic circulation of human patients [56-60] and in the human post-mortem brain tissue [61, 62]. Experimental studies implicated $\mathrm{C} 3 \mathrm{a}$ as the key mediator of brain tissue injury in the acute phase after focal brain ischemia [63]. However, given the broad expression of $\mathrm{C} 3 \mathrm{aR}$ on the different cell types in the CNS, and the potential involvement of $\mathrm{C} 3 \mathrm{aR}$ in the regulation of several intracellular signaling pathways, the net effect of $\mathrm{C} 3 \mathrm{aR}$ activation on the long-term outcome may depend on the specific cell type and the timing of the response in relation to the ischemia onset. For example, the expression of $\mathrm{C} 3 \mathrm{aR}$ by astrocytes is increased by ischemia [27, 28, 36], and C3a was shown to promote astrocyte survival after ischemia through its inhibitory effect on ERK signaling-mediated apoptotic pathway and caspase-3 cleavage [36]. C3a protects neurons against excitotoxicity-induced cell death, but only when neurons are co-cultured with astrocytes [64]. Further, microglial cells treated with $\mathrm{C} 3 \mathrm{a}$ exhibit neuroprotective phenotype as evidenced by increased production of NGF [42]. 


\section{The Effects of C3aR Signaling in the Acute Phase After Ischemic Brain Injury}

In the first days after stroke, C3a levels in blood are elevated and in some stroke subtypes show association with unfavorable outcome [57, 59, 60,65]. The involvement of C3 in the pathophysiology of ischemic stroke is also supported by human genetic studies [66]. Indeed, C3a-C3aR signaling was shown to regulate bleeding time after tail injury and thrombosis in mice, and $\mathrm{C} 3 \mathrm{aR}$ deficient mice were less prone to experimental stroke and myocardial infarction [67]. In the acute phase after stroke, endothelial activation and leukocyte recruitment into the brain are reduced in mice lacking $\mathrm{C} 3$ and $\mathrm{C} 3 \mathrm{aR}$ [46]. C3 deficiency and pre-treatment of mice with $\mathrm{C} 3 \mathrm{aR}$ antagonist reduced granulocyte infiltration, infarct volume and neurological deficit scores assessed $24 \mathrm{~h}$ after transient cerebral ischemia [63], and mice that were treated with SB290157, a C3aR antagonist [68], starting before the induction of transient ischemia developed smaller infarcts as assessed 7 days after ischemia [69]. Another study demonstrated that the C3aR antagonist pre-treatment reduced the expression of ICAM-1 protein on endothelial cells and granulocyte infiltration to the brain parenchyma [70]. Even when administered $2 \mathrm{~h}$ after the induction of cerebral ischemia, $\mathrm{C} 3 \mathrm{aR}$ antagonist treatment reduced functional impairment, infarct volume, edema and hemorrhagic transformation assessed $48 \mathrm{~h}$ later [71]. In an in vitro ischemia model, C3a led to increased endothelial permeability [72], and $\mathrm{C} 3 \mathrm{aR}$ antagonist administration preserved the integrity of endothelial cell tight junctions and reduced the activation of ERK, suggesting that endothelial C3aR may act via ERK signaling [73]. These results point to therapeutic benefits of systemic inhibition of $\mathrm{C} 3 \mathrm{aR}$ signaling in the acute phase after ischemic injury to the adult brain through mitigating the pro-inflammatory effects of $\mathrm{C} 3 \mathrm{a}-\mathrm{C} 3 \mathrm{aR}$ signaling on endothelial cells and reducing the recruitment of inflammatory cells from the systemic circulation.

In contrast to the ischemic injury to the adult brain, in a model of neonatal hypoxic-ischemic brain injury, mice expressing biologically active $\mathrm{C} 3 \mathrm{a}$ under the control of the glial fibrillary acidic protein promoter $(G F A P-C 3 a)$, i.e. expressing C3a in reactive astrocytes, showed reduced brain tissue loss assessed 3 weeks later [7]. In the same study, single intraventricular injection of $\mathrm{C} 3$ a mitigated cognitive function impairment due to neonatal hypoxia-ischemia in control mice but not in mice lacking $\mathrm{C} 3 \mathrm{aR}\left(\mathrm{C} a \mathrm{R}^{-/-}\right)$ 6 weeks later [7]. Importantly, mice that received intranasal treatment with C3a once daily for 3 days starting $1 \mathrm{~h}$ after hypoxia-ischemia induction at postnatal day 9 were protected against cognitive impairment observed in vehicle treated mice 6 weeks after hypoxia-ischemia [8]. Thus, in the acutely injured immature brain, $\mathrm{C} 3 \mathrm{a}-\mathrm{C} 3 \mathrm{aR}$ signaling appears to promote recovery. Therapeutic hypothermia, the only intervention that improves clinical outcome after neonatal hypoxic-ischemic encephalopathy, was shown to increase the levels of $\mathrm{C} 3 \mathrm{a}$ in the brain and plasma, and to lead to the upregulation of $\mathrm{C} 3 \mathrm{aR}$ in the brain in a rat model of hypoxic-ischemic encephalopathy [74]. These results point to $\mathrm{C} 3 \mathrm{a}-\mathrm{C} 3 \mathrm{aR}$ signaling as a mediator of the neuroprotective effects of hypothermia. Together, these studies support the notion that the cellular functions of $\mathrm{C} 3 \mathrm{aR}$ signaling differ profoundly depending on the developmental stage of the neural tissue.

\section{C3a-C3aR and Post-stroke Neural Plasticity}

Ischemic injury to the brain is known to trigger a range of endogenous plasticity and repair processes, including proliferation, differentiation and migration of neural stem and progenitor cells [75-77], axonal sprouting, dendritic arborization and synaptogenesis, that lead to rewiring of the existing neuronal connections and the formation of new ones [78, 79]. The structural and functional constituents of ischemia-induced neural plasticity are recognized as critically important contributors to recovery of function after stroke and other CNS injuries [1]. There is growing evidence for the role of $\mathrm{C} 3 \mathrm{a}-\mathrm{C} 3 \mathrm{aR}$ signaling in stimulating adaptive neural plasticity responses after ischemic brain injury. These findings point to the use of $\mathrm{C} 3 \mathrm{aR}$ agonists as a therapeutic strategy to facilitate functional recovery in the post-acute and chronic phase after ischemic brain injury, Table 2 .
Table 2 The functions of $\mathrm{C} 3 \mathrm{a}$ in the acute, post-acute and chronic phase after ischemic brain injury

\begin{tabular}{lll}
\hline & Function & References \\
\hline Acute phase & Leukocyte recruitment & {$[46,63,69,70]$} \\
& Inflammatory endothelial activation & {$[46,70]$} \\
& Endothelial cell and blood-brain barrier dysfunction & {$[71-73]$} \\
Post-acute and & Post-stroke neurogenesis & {$[26,80]$} \\
chronic phase & Post-stroke synaptogenesis & {$[89]$} \\
& Post-stroke expression of GAP-43, marker of axonal and glial plasticity & {$[89]$} \\
& Modulation of reactive gliosis & {$[8]$} \\
& Neuroprotection, survival of astrocytes after ischemic stress & {$[7,36]$} \\
\hline
\end{tabular}




\section{C3aR and Post-stroke Neurogenesis}

$\mathrm{C} 3 \mathrm{aR}$ is expressed by hippocampal neural stem cells in vitro as well as migrating neuroblasts in vivo [26], and in vitro studies show that $\mathrm{C} 3 \mathrm{a}$ stimulates neural progenitor cell differentiation [31]. C3a also regulates the migration of adult neural progenitor cells in response to other environmental clues such as stromal derived factor $1 \alpha$ [31]. The contention that C3aR signaling acts as a positive regulator of adult neurogenesis is further supported by in vivo evidence showing that hippocampal and subventricular zone neurogenesis is impaired in mice constitutively lacking $\mathrm{C} 3 \mathrm{aR}$ or $\mathrm{C} 3$, and mice treated with C3aR antagonist SB 290157 [26]. The stimulatory effect of $\mathrm{C} 3 \mathrm{aR}$ signaling on basal adult neurogenesis was confirmed by other investigators, who observed reduced number of proliferating doublecortin-positive neural progenitor cells in the subventricular zone of unchallenged mice treated with the same C3aR antagonist [69].

Despite larger infarct, the $\mathrm{C} 3$ deficient mice had reduced neurogenic response in the ipsilesional subventricular zone and in the peri-infarct region after focal cerebral ischemia induced by middle cerebral artery occlusion at both 7 and 21 days after ischemia [26]. These findings point to $\mathrm{C} 3$ activation products as positive regulators of post-stroke neurogenesis and neuroprotection. In a model of ischemic stroke induced by photothrombosis - which results in ischemic lesion with minimal or no penumbra, and thus allows to study the effects of $\mathrm{C} 3 \mathrm{aR}$ signaling on neural plasticity and functional recovery independent of neuroprotection - we showed that C3a overexpression in the GFAP-C3a mice increased whereas $\mathrm{C} 3 \mathrm{aR}$ deficiency decreased the number of newly born neurons in the peri-infarct region on day 21 after stroke despite comparable infarct volumes [80]. These results strongly support the contention that $\mathrm{C} 3 \mathrm{a}-\mathrm{C} 3 \mathrm{aR}$ signaling stimulates the stroke-induced neurogenic response. Although the activity of the GFAP promoter and thus of the C3a transgene is too low to affect the levels of basal hippocampal and subventricular zone neurogenesis in unchallenged adult GFAP-C3a mice [81], pronounced and persistent reactive gliosis in the peri-infarct tissue [82] results in sufficiently high transgene-derived C3a levels to impact post-stroke neurogenesis in this region.

On the other hand, daily systemic treatment with a low dose of the C3aR antagonist SB 290157 starting before the induction of transient focal cerebral ischemia increased the proliferation of neuronal precursor cells in the ipsilesional subventricular zone 7 days later [69]. As argued by the authors, in the absence of any effect of the same treatment protocol on subventricular zone neurogenesis in unchallenged mice, the positive effect of low dose $\mathrm{C} 3 \mathrm{aR}$ antagonist treatment on post-stroke neurogenesis is conceivably due to the inhibition of the inflammation including the reduced recruitment of activated T-lymphocytes rather than to the direct effect of the drug on the progenitor cells [69]. The specific mechanism of $\mathrm{C} 3 \mathrm{a}$ generation in an unchallenged neurogenic niche and the mechanisms of $\mathrm{C} 3 \mathrm{a}$ generation in the post-acute and chronic phase after stroke need to be elucidated in future studies.

\section{C3aR and Post-stroke Synaptic Plasticity}

In the developing brain, the complement system is involved in the regulation of the number of neuronal synapses. Specifically, transforming growth factor $\beta$ that is secreted by immature astrocytes triggers the neuronal expression of complement component $\mathrm{C} 1 \mathrm{q}$ in the developing visual thalamus [83, 84] and sensorimotor cortex [85]. Binding of C1q to externalized phosphatidylserine [86] leads to the deposition of $\mathrm{C} 3 \mathrm{~b}$ which tags the synapse for recognition by microglial complement receptor 3 (CR3) and subsequent elimination by phagocytosis [83, 87]. However, given that the development and experience-dependent plasticity of the binocular zone of the primary visual cortex was not altered in mice lacking $\mathrm{C} 1 \mathrm{q}$, the contribution of $\mathrm{Clq}$ to synapse elimination is not universal and instead appears to be context-dependent [88].

While the $\mathrm{C} 3 \mathrm{~b}$ fragment of $\mathrm{C} 3$, through its interaction with the CR3, drives the removal of neuronal synapses, at least during the CNS development, neuronal C3aR signaling promotes increase in synaptic strength through membrane localization of the $\alpha$-amino-3-hydroxy-5-methyl-4isoxazolepropionic acid receptor [35]. In addition, dendritic complexity is reduced in mice lacking neuronal $\mathrm{C} 3 \mathrm{aR}$ as well as in mice treated with a C3aR antagonist [35]. On the other hand, excessive activation of neuronal C3aR can lead to reduced complexity of dendrites and impair synaptic function [35]. In the post-stroke brain, C3a overexpression in the GFAP-C3a mice increased whereas C3aR deficiency decreased the density and size of glutamatergic pre-synaptic terminals in the peri-infarct region as well as in the contralesional hemisphere in a manner that was cortical region- and cortical layer-specific. None of these parameters was altered in an unchallenged brain of these genetically modified mice [89]. The synaptogenic function of C3a-C3aR signaling in the post-stroke adult brain was further supported by the finding that mice that received daily intranasal treatment with C3a for 14 to 21 days starting 7 days after ischemia induction had higher density of pre-synaptic terminals and faster functional recovery that was sustained 4 weeks after cessation of the treatment [89].

\section{C3aR and Post-stroke Axonal Plasticity}

As a hallmark of CNS regeneration, axonal sprouting and plasticity are associated with reactivation of the intrinsic neuronal growth program and upregulation of the membrane phosphoprotein growth associated protein (GAP)-43 [90]. 
GAP-43 associates with axonal growth cones, is upregulated during reactive synaptogenesis and is used as marker of axonal sprouting and plasticity [91-93]. Astrocyte-derived GAP-43 has been shown to promote neuronal survival and glial plasticity [94]. The stroke-induced increase in GAP-43 expression in the peri-infarct region was reduced in mice constitutively lacking $\mathrm{C} 3 \mathrm{aR}$, while it was further increased when C3a was expressed in reactive astrocytes or administered intranasally starting 7 days after stroke [89]. In light of the ischemia-induced upregulation of $\mathrm{C} 3$ in sprouting neurons [95] and the stimulatory effect of $\mathrm{C} 3 \mathrm{a}$ on neurite outgrowth in vitro [31], these findings implicate $\mathrm{C} 3 \mathrm{a}-\mathrm{C} 3 \mathrm{aR}$ as a contributing factor in post-stroke axonal plasticity.

\section{C3aR and Glial Responses to Ischemia}

Given the evidence for the involvement of neuronal C3aR in the modulation of synaptic strength and dendritic morphology [35], and the role of C3a-C3aR in neural progenitor cell differentiation and migration [31], the increase in periinfarct neurogenesis, upregulation of expression of GAP-43 and increased number of pre-synaptic terminals, particularly glutamatergic terminals in C3a overexpressing and C3a treated mice [80, 89], are arguably at least in part due to a direct effect of $\mathrm{C} 3 \mathrm{a}$ on neurons. However, given its broad expression and the multitude of functions of $\mathrm{C} 3 \mathrm{aR}$ in the different cell types in the brain (Table 1), the effects of C3a$\mathrm{C} 3 \mathrm{aR}$ signaling on the plasticity of the post-ischemic brain can be also indirect through the modulation of the functions of astrocytes, microglia, endothelial cells, stem / progenitor cells, and the epithelial cells in the choroid plexus.

Within the first hour after the ischemia onset, microglia become activated [96] and the density of activated microglia/macrophages in the periphery of the ischemic lesion is increased for several weeks [97]. Astrocytes in the periinfarct region change their expression profile [98], proliferate and form a glial scar that restricts the damaged area and prevents the infiltrating leukocytes from spreading into the surrounding healthy parenchyma [99-103]. Peri-infarct reactive gliosis persists for at least several weeks [82]. Genetic attenuation of reactive gliosis achieved by ablation of genes coding for intermediate filament (nanofilament) proteins GFAP and vimentin [104-106], markers of astrocyte reactivity [103, 107], led to more pronounced neuronal loss in the acute phase after ischemic stroke [99] and after retinal ischemia-reperfusion [108], but not in neonatal hypoxicischemic brain injury [109]. Reduced expression of GFAP in the peri-infarct cortex was associated with increased axonal sprouting and better functional recovery 7 days after ischemic stroke [110]. In the post-ischemic brain, astrocytes participate in several aspects of remodeling of the neural tissue and the peri-infarct networks, such as phagocytic clearance of tissue debris, formation of new synapses and neurogenesis [111-114]. Our findings that intranasal treatment with $\mathrm{C} 3 \mathrm{a}$ improved functional outcome and reduced the expression of GFAP and the density of microglia/macrophages in the ipsilesional hippocampus after neonatal hypoxic-ischemic brain injury [8], suggest that the protective effects of $\mathrm{C} 3 \mathrm{a}-\mathrm{C} 3 \mathrm{aR}$ signaling in the immature brain may be mediated through the modulation of glial responses. The functions of $\mathrm{C} 3 \mathrm{a}-\mathrm{C} 3 \mathrm{aR}$ signaling in the regulation of reactive gliosis in the context of ischemic brain injury in adults and a detailed characterization of the impact of $\mathrm{C} 3 \mathrm{a}-\mathrm{C} 3 \mathrm{aR}$ signaling on the phenotypes of reactive astrocytes [115] remain to be investigated.

The multiple roles of C3a-C3aR signaling in CNS responses to ischemic injury are summarized in Table 2.

\section{C3aR and Neurodegeneration}

The complement system is an important driver of age-related synapse loss and cognitive decline [116], and a prominent factor in neurodegeneration [35, 50, 117-121]. The elimination of synapses mediated by $\mathrm{C} 3 \mathrm{~b}-\mathrm{CR} 3$ may be re-activated in neurodegenerative diseases such as glaucoma [122] and Alzheimer's disease [118]. C3 deficient mice have better hippocampus-dependent learning and memory functions [123], and are protected from age-related region-specific loss of neurons and synapses in the hippocampus, age-related cognitive decline [116], and axotomy-induced inhibitory synapse removal [124]. In spite of higher amyloid- $\beta$ plaque load, C3 deficient mice were also protected against Alzheimer type of neurodegeneration and cognitive decline [125]. These results implicate the involvement of the complement system and in particular $\mathrm{C} 3$, in amyloid- $\beta$ clearance and amyloid- $\beta$ induced synapse elimination. Identical or similar mechanisms can operate also in the post-stroke brain. Indeed, through a number of mechanisms, including impaired perivascular space integrity, reduced efficiency of the glymphatic system, inflammation, hypoxia, and bloodbrain barrier dysfunction, stroke can accelerate amyloid- $\beta$ deposition in brain parenchyma, which in turn leads to synaptic dysfunction, cognitive decline and dementia (reviewed in [126]).

Neuronal death, reactive gliosis, and axonal degeneration occur also after stroke in remote brain regions that were not directly affected by the ischemic injury but had synaptic connections with neurons in the primary lesion site [127]. This so called post-stroke secondary degeneration has been linked to neurological deficits such as depression and cognitive impairment [128, 129], and can affect motor functionrelated outcome [127]. However, the underlying molecular mechanisms are not clear. In murine models of Alzheimer's disease, both neuronal and microglial C3aR signaling has been implicated in contributing to neurodegeneration [35, 
50]. Given that synaptic dysfunction and loss may be the initial steps in neurodegeneration [130,131], studies on the involvement of the complement system, C3a-C3aR and in particular C3b-CR3 signaling in the elimination of synapses in the regions affected by secondary degeneration in the post-stroke brain are warranted.

\section{Future Directions}

Whereas complement activation, and $\mathrm{C} 3 \mathrm{a}$ in particular, can contribute to endothelial cell activation, inflammatory cell recruitment and tissue injury in the acute phase after cerebral ischemia, C3a-C3aR signaling evidently also supports functional recovery by stimulating post-stroke neural plasticity including cell replacement, reorganization of axonal circuitry, and synaptogenesis. After intranasal administration, therapeutic peptides are transported mainly via peri-vascular bulk flow along the olfactory and trigeminal nerves and reach the brain and the cerebrospinal fluid within minutes [132]. The findings of the plasticity- and recovery-promoting effects of $\mathrm{C} 3 \mathrm{a}$ given via this clinically highly feasible and non-invasive route are particularly intriguing as the therapeutic benefit was achieved when treatment was initiated as late as 7 days after stroke. The available data point to intranasal delivery of $\mathrm{C} 3 \mathrm{aR}$ agonists in the post-acute phase as an attractive approach to improve functional recovery after ischemic stroke. Given the lack of functional improvement promoting pharmacological therapies in the post-acute and chronic phase after stroke, clinical translation of these findings is warranted. The broad therapeutic window would allow the majority if not all stroke survivors to benefit from such a treatment.

Acknowledgements The authors' research has been supported by the Swedish Research Council (2017-02255 and 2017 -00991), ALF Gothenburg (146051 and 716591), The Swedish Society for Medical Research, Hjärnfonden/The Swedish Brain Foundation, AFA Research Foundation, Söderberg's Foundations, Sten A. Olsson Foundation for Research and Culture, Hagströmer's Foundation Millennium, Amlöv's Foundation, Peter Eriksson's Foundation, E. Jacobson's Donation Fund, VINNOVA, the Swedish Stroke Foundation, NanoNet COST Action (BM1002), and EU FP 7 Program TargetBraIn (279017).

Funding Open access funding provided by University of Gothenburg.

\section{Declarations}

Conflict of interest M. Pekna, A. Stokowska, and M. Pekny are named as inventors on a patent application including claims to use of $\mathrm{C} 3 \mathrm{a}$ and $\mathrm{C} 3 \mathrm{a}$ receptor agonists for treatment of ischemic brain injury.

Open Access This article is licensed under a Creative Commons Attribution 4.0 International License, which permits use, sharing, adaptation, distribution and reproduction in any medium or format, as long as you give appropriate credit to the original author(s) and the source, provide a link to the Creative Commons licence, and indicate if changes were made. The images or other third party material in this article are included in the article's Creative Commons licence, unless indicated otherwise in a credit line to the material. If material is not included in the article's Creative Commons licence and your intended use is not permitted by statutory regulation or exceeds the permitted use, you will need to obtain permission directly from the copyright holder. To view a copy of this licence, visit http://creativecommons.org/licenses/by/4.0/.

\section{References}

1. Pekna M, Pekny M, Nilsson M (2012) Modulation of neural plasticity as a basis for stroke rehabilitation. Stroke 43:2819-2828

2. Ten VS, Wu EX, Tang H, Bradley-Moore M, Fedarau MV, Ratner VI, Stark RI, Gingrich JA, Pinsky DJ (2004) Late measures of brain injury after neonatal hypoxia-ischemia in mice. Stroke 35:2183-2188

3. Fleiss B, Gressens P (2012) Tertiary mechanisms of brain damage: a new hope for treatment of cerebral palsy? Lancet Neurol 11:556-566

4. Geddes R, Vannucci RC, Vannucci SJ (2001) Delayed cerebral atrophy following moderate hypoxia-ischemia in the immature rat. Develop Neurosci 23:180-185

5. Stone BS, Zhang J, Mack DW, Mori S, Martin LJ, Northington FJ (2008) Delayed neural network degeneration after neonatal hypoxia-ischemia. Ann Neurol 64:535-546

6. Järlestedt K, Atkins AL, Hagberg H, Pekna M, Mallard C (2011) Trace fear conditioning detects hypoxic-ischemic brain injury in neonatal mice. Dev Neurosci 33:222-230

7. Järlestedt K, Rousset CI, Ståhlberg A, Sourkova H, Atkins AL, Thornton C, Barnum SR, Wetsel RA, Dragunow M, Pekny M, Mallard C, Hagberg H, Pekna M (2013) Receptor for complement peptide $\mathrm{C} 3 \mathrm{a}$ : a therapeutic target for neonatal hypoxicischemic brain injury. FASEB J 27:3797-3804

8. Moran J, Stokowska A, Walker FR, Mallard C, Hagberg H, Pekna M (2017) Intranasal C3a treatment ameliorates cognitive impairment in a mouse model of neonatal hypoxic-ischemic brain injury. Exp Neurol 290:74-84

9. Papile LA, Baley JE, Benitz W, Cummings J, Carlo WA, Eichenwald E, Kumar P, Polin RA, Tan RC, Wang KS (2014) Hypothermia and neonatal encephalopathy. Pediatrics 133:1146-1150

10. Bajic G, Degn SE, Thiel S, Andersen GR (2015) Complement activation, regulation, and molecular basis for complementrelated diseases. EMBO J 34:2735-2757

11. Pekna M, Pekny M (2021) The complement system: a powerful modulator and effector of astrocyte function in the healthy and diseased central nervous system. Cells 10:1812

12. Ember JA, Jagels MA, Hugli T (1998) Characterization of complement anaphylatoxins and biological responses. In: Volanakis JE, Frank MM (eds) The human complement system in health and disease. Marcel Dekker, New York, pp 241-284

13. Klos A, Tenner AJ, Johswich KO, Ager RR, Reis ES, Kohl J (2009) The role of the anaphylatoxins in health and disease. Mol Immunol 46:2753-2766

14. Quell KM, Karsten CM, Kordowski A, Almeida LN, Briukhovetska D, Wiese AV, Sun J, Ender F, Antoniou K, Schröder T, Schmudde I, Berger JL, König P, Vollbrandt T, Laumonnier Y, Köhl J (2017) Monitoring C3aR expression using a floxed tdTomato-C3aR reporter knock-in mouse. J Immunol 199:688

15. Coulthard LG, Woodruff TM (2015) Is the complement activation product $\mathrm{C} 3$ a a proinflammatory molecule? Re-evaluating the evidence and the myth. J Immunol 194:3542-3548 
16. Shinjyo N, Kagaya W, Pekna M (2021) Interaction between the complement system and infectious agents - A potential mechanistic link to neurodegeneration and dementia. Front Cell Neurosci 15:710390

17. Matsushita M, Fujita T (1995) Cleavage of the third component of complement (C3) by mannose-binding protein-associated serine protease (MASP) with subsequent complement activation. Immunobiology 194:443-448

18. Liszewski MK, Kolev M, Le Friec G, Leung M, Bertram PG, Fara AF, Subias M, Pickering MC, Drouet C, Meri S, Arstila TP, Pekkarinen PT, Ma M, Cope A, Reinheckel T, Rodriguez de Cordoba S, Afzali B, Atkinson JP, Kemper C (2013) Intracellular complement activation sustains $\mathrm{T}$ cell homeostasis and mediates effector differentiation. Immunity 39:1143-1157

19. Yuan X, Shan M, You R, Frazier MV, Hong MJ, Wetsel RA, Drouin S, Seryshev A, Song LZ, Cornwell L, Rossen RD, Corry DB, Kheradmand F (2015) Activation of C3a receptor is required in cigarette smoke-mediated emphysema. Mucosal Immunol 8:874-885

20. Johnson U, Ohlsson K, Olsson I (1976) Effects of granulocyte neutral proteases on complement components. Scand J Immunol 5:421-426

21. Markiewski MM, Lambris JD (2007) The role of complement in inflammatory diseases from behind the scenes into the spotlight. Am J Pathol 171:715-727

22. Amara U, Flierl MA, Rittirsch D, Klos A, Chen H, Acker B, Bruckner UB, Nilsson B, Gebhard F, Lambris JD, Huber-Lang M (2010) Molecular intercommunication between the complement and coagulation systems. J Immunol 185:5628-5636

23. Hannedouche S, Beck V, Leighton-Davies J, Beibel M, Roma G, Oakeley EJ, Lannoy V, Bernard J, Hamon J, Barbieri S, Preuss I, Lasbennes MC, Sailer AW, Suply T, Seuwen K, Parker CN, Bassilana F (2013) Identification of the C3a receptor (C3AR1) as the target of the VGF-derived peptide TLQP21 in rodent cells. J Biol Chem 288:27434-27443

24. Trani E, Giorgi A, Canu N, Amadoro G, Rinaldi AM, Halban PA, Ferri GL, Possenti R, Schininà ME, Levi A (2002) Isolation and characterization of VGF peptides in rat brain. Role of $\mathrm{PC} 1 / 3$ and PC2 in the maturation of VGF precursor. J Neurochem 81:565-574

25. Coulthard LG, Hawksworth OA, Conroy J, Lee JD, Woodruff TM (2018) Complement C3a receptor modulates embryonic neural progenitor cell proliferation and cognitive performance. Mol Immunol 101:176-181

26. Rahpeymai Y, Hietala MA, Wilhelmsson U, Fotheringham A, Davies I, Nilsson AK, Zwirner J, Wetsel RA, Gerard C, Pekny M, Pekna M (2006) Complement: a novel factor in basal and ischemia-induced neurogenesis. EMBO J 25:1364-1374

27. Davoust N, Jones J, Stahel PF, Ames RS, Barnum SR (1999) Receptor for the C3a anaphylatoxin is expressed by neurons and glial cells. Glia 26:201-211

28. van Beek J, Bernaudin M, Petit E, Gasque P, Nouvelot A, MacKenzie ET, Fontaine M (2000) Expression of receptors for complement anaphylatoxins $\mathrm{C} 3 \mathrm{a}$ and $\mathrm{C} 5 \mathrm{a}$ following permanent focal cerebral ischemia in the mouse. Exp Neurol 161:373-382

29. Benard M, Gonzalez BJ, Schouft M-T, Falluel-Morel A, Chan P, Vaudry H, Fontaine M (2004) Characterization of C3a and C5a Receptors in rat cerebellar granule neurons during maturation. Neuroprotective effect of C5a against apoptotic cell death. J Biol Chem 279:43487-43496

30. Pedersen ED, Froyland E, Kvissel AK, Pharo AM, Skalhegg BS, Rootwelt T, Mollnes TE (2007) Expression of complement regulators and receptors on human NT2-N neurons-effect of hypoxia and reoxygenation. Mol Immunol 44:2459-2468

31. Shinjyo N, Ståhlberg A, Dragunow M, Pekny M, Pekna M (2009) Complement-derived anaphylatoxin C3a regulates in vitro differentiation and migration of neural progenitor cells in vitro. Stem Cells 27:2824-2832

32. Benard M, Raoult E, Vaudry D, Leprince J, Falluel-Morel A, Gonzalez BJ, Galas L, Vaudry H, Fontaine M (2008) Role of complement anaphylatoxin receptors $(\mathrm{C} 3 \mathrm{aR}, \mathrm{C} 5 \mathrm{aR})$ in the development of the rat cerebellum. Mol Immunol 45:3767-3774

33. Gorelik A, Sapir T, Haffner-Krausz R, Olender T, Woodruff TM, Reiner O (2017) Developmental activities of the complement pathway in migrating neurons. Nature Commun 8:15096

34. Pozo-Rodrigálvarez A, Ollaranta R, Skoog J, Pekny M, Pekna M (2021) Hyperactive behavior and altered brain morphology in adult complement $\mathrm{C} 3 \mathrm{a}$ receptor deficient mice. Front Immunol 12:604812

35. Lian H, Yang L, Cole A, Sun L, Chiang AC, Fowler SW, Shim DJ, Rodriguez-Rivera J, Taglialatela G, Jankowsky JL, Lu HC, Zheng H (2015) NFkappaB-activated astroglial release of complement C3 compromises neuronal morphology and function associated with Alzheimer's disease. Neuron 85:101-115

36. Shinjyo N, de Pablo Y, Pekny M, Pekna M (2016) Complement peptide $\mathrm{C} 3$ a promotes astrocyte survival in response to ischemic stress. Mol Neurobiol 53:3076-3087

37. Sayah S, Jauneau AC, Patte C, Tonon MC, Vaudry H, Fontaine M (2003) Two different transduction pathways are activated by C3a and C5a anaphylatoxins on astrocytes. Mol Brain Res 112:53-60

38. Sayah S, Ischenko A, Zhakhov A, Bonnard AS, Fontaine M (1999) Expression of cytokines by human astrocytomas following stimulation by $\mathrm{C} 3 \mathrm{a}$ and $\mathrm{C} 5 \mathrm{a}$ anaphylatoxins: specific increase in interleukin-6 mRNA expression. J Neurochem 72:2426-2436

39. Jauneau AC, Ischenko A, Chan P, Fontaine M (2003) Complement component anaphylatoxins upregulate chemokine expression by human astrocytes. FEBS Lett 537:17-22

40. Jauneau A-C, Ischenko A, Chatagner A, Benard M, Chan P, Schouft M-T, Patte C, Vaudry H, Fontaine M (2006) Interleukin- $1 \beta$ and anaphylatoxins exert a synergistic effect on NGF expression by astrocytes. J Neuroinflamm 3:8

41. Möller T, Nolte C, Burger R, Verkhratsky A, Kettermann H (1997) Mechanisms of C5a and C3a complement fragmentinduced $[\mathrm{Ca} 2+] \mathrm{i}$ signaling in mouse microglia. J Neurosci $17: 615-624$

42. Heese K, Hock C, Otten U (1998) Inflammatory signals induce neurotropin expression in human microglial cells. J Neurochem 70:699-707

43. Lian H, Litvinchuk A, Chiang AC, Aithmitti N, Jankowsky JL, Zheng H (2016) Astrocyte-microglia cross talk through complement activation modulates amyloid pathology in mouse models of Alzheimer's disease. J Neurosci 36:577-589

44. Doolen S, Cook J, Riedl M, Kitto K, Kohsaka S, Honda CN, Fairbanks CA, Taylor BK, Vulchanova L (2017) Complement 3 a receptor in dorsal horn microglia mediates pronociceptive neuropeptide signaling. Glia 65:1976-1989

45. Monsinjon T, Gasque P, Chan P, Ischenko A, Brady JJ, Fontaine MC (2003) Regulation by complement C3a and C5a anaphylatoxins of cytokine production in human umbilical vein endothelial cells. FASEB J 17:1003-1014

46. Wu F, Zou Q, Ding X, Shi D, Zhu X, Hu W, Liu L, Zhou H (2016) Complement component C3a plays a critical role in endothelial activation and leukocyte recruitment into the brain. J Neuroinflamm 13:23

47. Propson NE, Roy ER, Litvinchuk A, Köhl J, Zheng H (2021) Endothelial C3a receptor mediates vascular inflammation and blood-brain barrier permeability during aging. J Clin Invest 131:e140966

48. Boire A, Zou Y, Shieh J, Macalinao DG, Pentsova E, Massague J (2017) Complement component 3 adapts the cerebrospinal fluid for leptomeningeal metastasis. Cell 168:1101-1113.e1113 
49. McCarthy JD, Cao Q, Winsor N, Van Limbergen J, Stadnyk AW (2018) The anaphylatoxin C3a primes model colonic epithelial cells for expression of inflammatory mediators through Goi. Mol Immunol 103:125-132

50. Litvinchuk A, Wan YW, Swartzlander DB, Chen F, Cole A, Propson NE, Wang Q, Zhang B, Liu Z, Zheng H (2018) Complement C3aR inactivation attenuates tau pathology and reverses an immune network deregulated in Tauopathy models and Alzheimer's disease. Neuron 100:1337-1353.e1335

51. Hu J, Yang Y, Wang M, Yao Y, Chang Y, He Q, Ma R, Li G (2019) Complement C3a receptor antagonist attenuates tau hyperphosphorylation via glycogen synthase kinase $3 \beta$ signaling pathways. Eur J Pharmacol 850:135-140

52. Gasque P, Fontaine M, Morgan BP (1995) Complement expression in human brain. Biosynthesis of terminal pathway components and regulators in human glial cells and cell lines. J Immunol 154:4726-4733

53. Gasque P, Ischenko A, Legoedec J, Mauger C, Schouft MT, Fontaine M (1993) Expression of the complement classical pathway by human glioma in culture. A model for complement expression by nerve cells. J Biol Chem 268:25068-25074

54. Gasque P, Julen N, Ischenko AM, Picot C, Mauger C, Chauzy C, Ripoche J, Fontaine M (1992) Expression of complement components of the alternative pathway by glioma cell lines. J Immunol 149:1381-1387

55. Thomas A, Gasque P, Vaudry D, Gonzalez B, Fontaine M (2000) Expression of a complete and functional complement system by human neuronal cells in vitro. Int Immunol 12:1015-1023

56. Pedersen ED, Waje-Andreassen U, Vedeler CA, Aamodt G, Mollnes TE (2004) Systemic complement activation following human acute ischaemic stroke. Clin Exp Immunol 137:117-122

57. Mocco J, Wilson DA, Komotar RJ, Sughrue ME, Coates K, Sacco RL, Elkind MSV, Connolly ES Jr (2006) Alterations in plasma complement levels after human ischemic stroke. Neurosurgery 59:28-33

58. Széplaki G, Szegedi R, Hirschberg K, Gombos T, Varga L, Karádi I, Entz L, Széplaki Z, Garred P, Prohászka Z, Füst G (2009) Strong complement activation after acute ischemic stroke is associated with unfavorable outcomes. Atherosclerosis 204:315-320

59. Stokowska A, Olsson S, Holmegaard L, Jood K, Blomstrand C, Jern C, Pekna M (2011) Plasma C3 and C3a levels in cryptogenic and large vessel disease stroke: associations with outcome. Cerebrovasc Dis 32:114-122

60. Stokowska A, Olsson S, Holmegaard L, Jood K, Blomstrand C, Jern C, Pekna M (2013) Cardioembolic and small vessel disease stroke show differences in associations between systemic $\mathrm{C} 3 \mathrm{lev}$ els and outcome. PLoS One 8:e72133

61. Lindsberg PJ, Ohman J, Lehto T, Karjalainen-Lindsberg ML, Paetau A, Wuorimaa T, Carpen O, Kaste M, Meri S (1996) Complement activation in the central nervous system following bloodbrain barrier damage in man. Ann Neurol 4:587-596

62. Pedersen ED, Løberg EM, Vege E, Daha MR, Maehlen J, Mollnes TE (2009) In situ deposition of complement in human acute brain ischaemia. Scand J Immunol 69:555-562

63. Mocco J, Mack WJ, Ducruet AF, Sosunov AA, Sughrue ME, Hassid BG, Nair MN, Laufer I, Komotar RJ, Holland MCH, Pinsky DJ, Connolly ES Jr (2006) Complement component C3 mediates inflammatory injury following focal cerebral ischemia. Circ Res 99:209-217

64. van Beek J, Nicole O, Ali C, Ischenko A, MacKenzie ET, Buisson A, Fontaine M (2001) Complement anaphylatoxin C3a is selectively protective against NMDA-induced neuronal cell death. Neuroreport 12:289-293

65. Mack WJ, Ducruet AF, Hickman ZL, Garrett MC, Albert EJ, Kellner CP, Mocco J, Connolly ES Jr (2007) Early plasma complement $\mathrm{C} 3 \mathrm{a}$ levels correlate with functional outcome after aneurysmal subarachnoid hemorrhage. Neurosurgery 61:255-261

66. Olsson S, Stokowska A, Holmegaard L, Jood K, Blomstrand C, Pekna M, Jern C (2011) Genetic variation in complement component $\mathrm{C} 3$ shows association with ischaemic stroke. Eur J Neurol 18:1272-1274

67. Sauter RJ, Sauter M, Reis ES, Emschermann FN, Nording H, Ebenhöch S, Kraft P, Münzer P, Mauler M, Rheinlaender J, Madlung J, Edlich F, Schäffer TE, Meuth SG, Duerschmied D, Geisler T, Borst O, Gawaz M, Kleinschnitz C, Lambris JD, Langer HF (2018) Functional relevance of the anaphylatoxin receptor $\mathrm{C} 3 \mathrm{aR}$ for platelet function and arterial thrombus formation marks an intersection point between innate immunity and thrombosis. Circulation 138:1720-1735

68. Ames RS, Lee D, Foley JJ, Jurewicz AJ, Tornetta MA, Bautsch W, Settmacher B, Klos A, Erhard KF, Cousins RD, Sulpizio AC, Hieble JP, McCafferty G, Ward KW, Adams JL, Bondinell WE, Underwood DC, Osborn RR, Badger AM, Sarau HM (2001) Identification of a selective nonpetide antagonist of the anaphylatoxin $\mathrm{C} 3$ a receptor that demonstrates antiinflammatory activity in animal models. J Immunol 166:6341-6348

69. Ducruet AF, Zacharia BE, Sosunov SA, Gigante PR, Yeh ML, Gorski JW, Otten ML, Hwang RY, Derosa PA, Hickman ZL, Sergot P, Connolly ESJ (2012) Complement inhibition promotes endogenous neurogenesis and sustained anti-inflammatory neuroprotection following reperfused stroke. PLoS ONE 7:e38664

70. Ducruet AF, Hassid BG, Mack WJ, Sosunov SA, Otten ML, Fusco DJ, Hickman ZL, Kim GH, Komotar RJ, Mocco J, Connolly ES (2008) C3a receptor modulation of granulocyte infiltration after murine focal cerebral ischemia is reperfusion dependent. J Cereb Blood Flow Metab 28:1048-1058

71. Ahmad S, Pandya C, Kindelin A, Bhatia K, Chaudhary R, Dwivedi AK, Eschbacher JM, Liu Q, Waters MF, Hoda MN, Ducruet AF (2020) C3a receptor antagonist therapy is protective with or without thrombolysis in murine thromboembolic stroke. Br J Pharmacol 177:2466-2477

72. Zhao XJ, Larkin TM, Lauver MA, Ahmad S, Ducruet AF (2017) Tissue plasminogen activator mediates deleterious complement cascade activation in stroke. PLoS ONE 12:e0180822

73. Ahmad S, Kindelin A, Khan SA, Ahmed M, Hoda MN, Bhatia K, Ducruet AF (2019) C3a receptor inhibition protects brain endothelial cells against oxygen-glucose deprivation/reperfusion. Exp Neurobiol 28:216-228

74. Shah TA, Nejad JE, Pallera HK, Lattanzio FA, Farhat R, Kumar PS, Hair PS, Bass WT, Krishna NK (2017) Therapeutic hypothermia modulates complement factor C3a and C5a levels in a rat model of hypoxic ischemic encephalopathy. Pediatr Res 81:654-662

75. Arvidsson A, Collin T, Kirik D, Kokaia Z, Lindvall O (2002) Neuronal replacement from endogenous precursors in the adult brain after stroke. Nat Med 8:963-970

76. Gu W, Brannstrom T, Wester P (2000) Cortical neurogenesis in adult rats after reversible photothrombotic stroke. J Cereb Blood Flow Metab 20:1166-1173

77. Osman AM, Porritt MJ, Nilsson M, Kuhn HG (2011) Long-term stimulation of neural progenitor cell migration after cortical ischemia in mice. Stroke 42:3559-3565

78. Carmichael ST (2003) Plasticity of cortical projections after stroke. Neuroscientist 9:64-75

79. Winship IR, Murphy TH (2009) Remapping the somatosensory cortex after stroke: insight from imaging the synapse to network. Neuroscientist 15:507-524

80. Stokowska A, Pekna M (2018) Complement C3a: shaping the plasticity of the post-stroke brain. In: Lapchak PA, Zhang JH 
(eds) Cellular and molecular approaches to regeneration \& repair. Springer, Cham, pp 521-541

81. Bogestål RY, Barnum SR, Smith PL, Mattisson V, Pekny M, Pekna M (2007) Signaling through C5aR is not involved in basal neurogenesis. J Neurosci Res 85:2892-2897

82. Nowicka D, Rogozinska K, Aleksy M, Witte OW, SkangielKramska J (2008) Spatiotemporal dynamics of astroglial and microglial responses after photothrombotic stroke in the rat brain. Acta Neurobiol Exp 68:155-168

83. Stevens B, Allen NJ, Vazquez LE, Howell GR, Christopherson KS, Nouri N, Micheva KD, Mehalow AK, Huberman AD, Stafford B, Sher A, Litke AM, Lambris JD, Smith SJ, John SW, Barres BA (2007) The classical complement cascade mediates CNS synapse elimination. Cell 131:1164-1178

84. Bialas AR, Stevens B (2013) TGF- $\beta$ signaling regulates neuronal $\mathrm{C} 1 \mathrm{q}$ expression and developmental synaptic refinement. Nat Neurosci 16:1773-1782

85. Chu Y, Jin X, Parada I, Pesic A, Stevens B, Barres BA, Prince DA (2010) Enhanced synaptic connectivity and epilepsy in C1q knockout mice. Proc Natl Acad Sci USA 107:7975-7980

86. Scott-Hewitt N, Perrucci F, Morini R, Erreni M, Mahoney M, Witkowska A, Carey A, Faggiani E, Schuetz LT, Mason S, Tamborini M, Bizzotto M, Passoni L, Filipello F, Jahn R, Stevens B, Matteoli M (2020) Local externalization of phosphatidylserine mediates developmental synaptic pruning by microglia. Embo J 39:e105380

87. Schafer DP, Lehrman EK, Kautzman AG, Koyama R, Mardinly AR, Yamasak R, Ransohoff RM, Greenberg ME, Barres BA, Stevens B (2012) Microglia sculpt postnatal neural circuits in an activity and complement-dependent manner. Neuron 74:691-705

88. Welsh CA, Stephany C, Sapp RW, Stevens B (2020) Ocular dominance plasticity in binocular primary visual cortex does not require C1q. J Neurosci 40:769-783

89. Stokowska A, Atkins AL, Moran J, Pekny T, Bulmer L, Pascoe MC, Barnum SR, Wetsel RA, Nilsson J, Dragunow M, Pekna M (2017) Complement peptide C3a stimulates neural plasticity after experimental brain ischemia. Brain 140:353-369

90. Carmichael ST, Archibeque I, Luke L, Nolan T, Momiy J, Li S (2005) Growth-associated gene expression after stroke: evidence for a growth-promoting region in peri-infarct cortex. Exp Neurol 193:291-311

91. Benowitz LI, Rodriguez WR, Neve RL (1990) The pattern of GAP-43 immunostaining changes in the rat hippocampal formation during reactive synaptogenesis. Brain Res Mol Brain Res 8:17-23

92. Benowitz LI, Routtenberg A (1997) GAP-43: an intrinsic determinant of neuronal development and plasticity. Trends Neurosci 20:84-91

93. Lin LH, Bock S, Carpenter K, Rose M, Norden JJ (1992) Synthesis and transport of GAP-43 in entorhinal cortex neurons and perforant pathway during lesion-induced sprouting and reactive synaptogenesis. Brain Res Mol Brain Res 14:147-153

94. Hung CC, Lin CH, Chang H, Wang CY, Lin SH, Hsu PC, Sun YY, Lin TN, Shie FS, Kao LS, Chou CM, Lee YH (2016) Astrocytic GAP43 induced by the TLR4/NF-kappaB/STAT3 axis attenuates astrogliosis-mediated microglial activation and neurotoxicity. J Neurosci 36:2027-2043

95. Li S, Overman JJ, Katsman D, Kozlov SV, Twiss CJD, Giger JL, Coppola RJ, Geschwind G, Carmichael DH ST (2010) An age-related sprouting transcriptome provides molecular control of axonal sprouting after stroke. Nat Neurosci 13:1496-1504

96. Rupalla K, Allegrini PR, Sauer D, Wiessner C (1998) Time course of microglia activation and apoptosis in various brain regions after permanent focal cerebral ischemia in mice. Acta Neuropathol 96:172-178
97. Hu X, Li P, Guo Y, Wang H, Leak RK, Chen S, Gao Y, Chen J (2012) Microglia/macrophage polarization dynamics reveal novel mechanism of injury expansion after focal cerebral ischemia. Stroke 43:3063-3070

98. Zamanian JL, Xu L, Foo LC, Nouri N, Zhou L, Giffard RG, Barres BA (2012) Genomic analysis of reactive astrogliosis. J Neurosci 32:6391-6410

99. Li L, Lundkvist A, Andersson D, Wilhelmsson U, Nagai N, Pardo AC, Nodin C, Stahlberg A, Aprico K, Larsson K, Yabe T, Moons L, Fotheringham A, Davies I, Carmeliet P, Schwartz JP, Pekna M, Kubista M, Blomstrand F, Maragakis N, Nilsson M, Pekny M (2008) Protective role of reactive astrocytes in brain ischemia. J Cereb Blood Flow Metab 28:468-481

100. Bardehle S, Kruger M, Buggenthin F, Schwausch J, Ninkovic J, Clevers H, Snippert HJ, Theis FJ, Meyer-Luehmann M, Bechmann I, Dimou L, Gotz M (2013) Live imaging of astrocyte responses to acute injury reveals selective juxtavascular proliferation. Nat Neurosci 16:580-586

101. Pekny M, Pekna M (2014) Astrocyte reactivity and reactive astrogliosis: costs and benefits. Physiol Rev 94:1077-1098

102. Pekny M, Pekna M, Messing A, Steinhäuser C, Lee JM, Parpura V, Hol EM, Sofroniew MV, Verkhratsky A (2016) Astrocytes: a central element in neurological diseases. Acta Neuropathol 131:323-345

103. Pekny M, Wilhelmsson U, Tatlisumak T, Pekna M (2019) Astrocyte activation and reactive gliosis-A new target in stroke? Neurosci Lett 689:45-55

104. Pekny M, Johansson CB, Eliasson C, Stakeberg J, Wallen A, Perlmann T, Lendahl U, Betsholtz C, Berthold CH, Frisen J (1999) Abnormal reaction to central nervous system injury in mice lacking fibrillary acidic protein and vimentin. J Cell Biol 145:503-514

105. Eliasson C, Sahlgren C, Berthold CH, Stakeberg J, Celis JE, Betsholtz C, Eriksson JE, Pekny M (1999) Intermediate filament protein partnership in astrocytes. J Biol Chem 274:23996-24006

106. Nakazawa T, Takeda M, Lewis GP, Cho KS, Jiao J, Wilhelmsson U, Fisher SK, Pekny M, Chen DF, Miller JW (2007) Attenuated glial reactions and photoreceptor degeneration after retinal detachment in mice deficient in glial fibrillary acidic protein and vimentin. Invest Ophthalmol Vis Sci 48:2760-2768

107. Hol EM, Pekny M (2015) Glial fibrillary acidic protein (GFAP) and the astrocyte intermediate filament system in diseases of the central nervous system. Curr Opin Cell Biol 32:121-130

108. Wunderlich KA, Tanimoto N, Grosche A, Zrenner E, Pekny M, Reichenbach A, Seeliger MW, Pannicke T, Perez MT (2015) Retinal functional alterations in mice lacking intermediate filament proteins glial fibrillary acidic protein and vimentin. Faseb j 29:4815-4828

109. Järlestedt K, Rousset CI, Faiz M, Wilhelmsson U, Stahlberg A, Sourkova H, Pekna M, Mallard C, Hagberg H, Pekny M (2010) Attenuation of reactive gliosis does not affect infarct volume in neonatal hypoxic-ischemic brain injury in mice. PLoS ONE 5:e10397

110. Joy MT, Ben Assayag E, Shabashov-Stone D, Liraz-Zaltsman S, Mazzitelli J, Arenas M, Abduljawad N, Kliper E, Korczyn AD, Thareja NS, Kesner EL, Zhou M, Huang S, Silva TK, Katz N, Bornstein NM, Silva AJ, Shohami E, Carmichael ST (2019) CCR5 Is a therapeutic target for recovery after stroke and traumatic brain injury. Cell 176:1143-1157.e1113

111. Morizawa YM, Hirayama Y, Ohno N, Shibata S, Shigetomi E, Sui Y, Nabekura J, Sato K, Okajima F, Takebayashi H, Okano H, Koizumi S (2017) Reactive astrocytes function as phagocytes after brain ischemia via ABCA1-mediated pathway. Nat Commun 8:28

112. Christopherson KS, Ullian EM, Stokes CC, Mullowney CE, Hell JW, Agah A, Lawler J, Mosher DF, Bornstein P, Barres 
BA (2005) Thrombospondins are astrocyte-secreted proteins that promote CNS synaptogenesis. Cell 120:421-433

113. Magnusson JP, Göritz C, Tatarishvili J, Dias DO, Smith EM, Lindvall O, Kokaia Z, Frisén J (2014) A latent neurogenic program in astrocytes regulated by Notch signaling in the mouse. Science 346:237-241

114. Pekny M, Nilsson M (2005) Astrocyte activation and reactive gliosis. Glia 50:427-434

115. Escartin C, Galea E, Lakatos A, O'Callaghan JP, Petzold GC, Serrano-Pozo A, Steinhäuser C, Volterra A, Carmignoto G, Agarwal A, Allen NJ, Araque A, Barbeito L, Barzilai A, Bergles DE, Bonvento G, Butt AM, Chen WT, Cohen-Salmon M, Cunningham C, Deneen B, De Strooper B, Díaz-Castro B, Farina C, Freeman M, Gallo V, Goldman JE, Goldman SA, Götz M, Gutiérrez A, Haydon PG, Heiland DH, Hol EM, Holt MG, Iino M, Kastanenka KV, Kettenmann H, Khakh BS, Koizumi S, Lee CJ, Liddelow SA, MacVicar BA, Magistretti P, Messing A, Mishra A, Molofsky AV, Murai KK, Norris CM, Okada S, Oliet SHR, Oliveira JF, Panatier A, Parpura V, Pekna M, Pekny M, Pellerin L, Perea G, Pérez-Nievas BG, Pfrieger FW, Poskanzer KE, Quintana FJ, Ransohoff RM, Riquelme-Perez M, Robel S, Rose CR, Rothstein JD, Rouach N, Rowitch DH, Semyanov A, Sirko S, Sontheimer H, Swanson RA, Vitorica J, Wanner IB, Wood LB, Wu J, Zheng B, Zimmer ER, Zorec R, Sofroniew MV, Verkhratsky A (2021) Reactive astrocyte nomenclature, definitions, and future directions. Nat Neurosci 24:312-325

116. Shi Q, Colodner KJ, Matousek SB, Merry K, Hong S, Kenison JE, Frost JL, Le KX, Li S, Dodart JC, Caldarone BJ, Stevens B, Lemere CA (2015) Complement C3-deficient mice fail to display age-related hippocampal decline. J Neurosci 35:13029-13042

117. Woodruff TM, Costantini KJ, Crane JW, Atkin JD, Monk PN, Taylor SM, Noakes PG (2008) The complement factor C5a contributes to pathology in a rat model of amyotrophic lateral sclerosis. J Immunol 181:8727-8734

118. Hong S, Beja-Glasser VF, Nfonoyim BM, Frouin A, Li S, Ramakrishnan S, Merry KM, Shi Q, Rosenthal A, Barres BA, Lemere CA, Selkoe DJ, Stevens B (2016) Complement and microglia mediate early synapse loss in Alzheimer mouse models. Science 352:712-716

119. Dejanovic B, Huntley MA, De Mazière A, Meilandt WJ, Wu T, Srinivasan K, Jiang Z, Gandham V, Friedman BA, Ngu H, Foreman O, Carano RAD, Chih B, Klumperman J, Bakalarski C, Hanson JE, Sheng M (2018) Changes in the synaptic proteome in Tauopathy and rescue of tau-induced synapse loss by C1q antibodies. Neuron 100:1322-1336.e1327

120. Wu T, Dejanovic B, Gandham VD, Gogineni A, Edmonds R, Schauer S, Srinivasan K, Huntley MA, Wang Y, Wang TM, Hedehus M, Barck KH, Stark M, Ngu H, Foreman O, Meilandt WJ, Elstrott J, Chang MC, Hansen DV, Carano RAD, Sheng M, Hanson JE (2019) Complement C3 is activated in human AD brain and is required for neurodegeneration in mouse models of amyloidosis and tauopathy. Cell Rep 28:2111-2123.e2116

121. Schartz ND, Tenner AJ (2020) The good, the bad, and the opportunities of the complement system in neurodegenerative disease. J Neuroinflamm 17:354
122. Howell GR, Macalinao DG, Sousa GL, Walden M, Soto I, Kneeland SC, Barbay JM, King BL, Marchant JK, Hibbs M, Stevens B, Barres BA, Clark AF, Libby RT, John SW (2011) Molecular clustering identifies complement and endothelin induction as early events in a mouse model of glaucoma. J Clin Invest 121:1429-1444

123. Perez-Alcazar M, Daborg J, Stokowska A, Wasling P, Björefeldt A, Kalm M, Zetterberg H, Carlström KE, Blomgren K, E CT, Hanse E, Pekna M (2014) Altered cognitive performance and synaptic function in the hippocampus of mice lacking C3. Exp Neurol 253:154-164

124. Berg A, Zelano J, Stephan A, Thams S, Barres BA, Pekny M, Pekna M, Cullheim S (2012) Reduced removal of synaptic terminals from axotomized spinal motoneurons in the absence of complement C3. Exp Neurol 237:8-17

125. Shi Q, Chowdhury S, Ma R, Le KX, Hong S, Caldarone BJ, Stevens B, Lemere CA (2017) Complement C3 deficiency protects against neurodegeneration in aged plaque-rich APP/PS1 mice. Sci Transl Med 9:eaaf6295

126. Goulay R, Mena Romo L, Hol EM, Dijkhuizen RM (2020) From Stroke to dementia: a comprehensive review exposing tight interactions between stroke and amyloid- $\beta$ formation. Transl Stroke Res 11:601-614

127. Zhang J, Zhang Y, Xing S, Liang Z, Zeng J (2012) Secondary neurodegeneration in remote regions after focal cerebral infarction: a new target for stroke management? Stroke 43:1700-1705

128. Kronenberg G, Balkaya M, Prinz V, Gertz K, Ji S, Kirste I, Heuser I, Kampmann B, Hellmann-Regen J, Gass P, Sohr R, Hellweg R, Waeber C, Juckel G, Hortnagl H, Stumm R, Endres M (2012) Exofocal dopaminergic degeneration as antidepressant target in mouse model of poststroke depression. Biol Psychiatry $72: 273-281$

129. Jones KA, Zouikr I, Patience M, Clarkson AN, Isgaard J, Johnson SJ, Spratt N, Nilsson M, Walker FR (2015) Chronic stress exacerbates neuronal loss associated with secondary neurodegeneration and suppresses microglial-like cells following focal motor cortex ischemia in the mouse. Brain Behav Immun 48:57-67

130. Cunningham C, Deacon R, Wells H, Boche D, Waters S, Diniz CP, Scott H, Rawlins JN, Perry VH (2003) Synaptic changes characterize early behavioural signs in the ME7 model of murine prion disease. Eur J Neurosci 17:2147-2155

131. Conforti L, Adalbert R, Coleman MP (2007) Neuronal death: where does the end begin? Trends Neurosci 30:159-169

132. Lochhead JJ, Thorne RG (2012) Intranasal delivery of biologics to the central nervous system. Adv Drug Deliv Rev 64:614-628

Publisher's Note Springer Nature remains neutral with regard to jurisdictional claims in published maps and institutional affiliations. 